Тимощук О.М., Дакі О.А., Бойко О.А., Карадобрій Т. А.

\title{
АНАЛІТИЧНИЙ ОГЛЯД АДАПТИВНИХ СИСТЕМ КЕРУВАННЯ СУДНОМ ТА ШЛЯХИ ЇХ ПОБУДОВИ
}

В статті відображаються основні результати аналізу джерел інформаџіі що стосується побудови адаптивних систем щодо управління судном. На ряду з аналітичним оглядом технічних рішень систем керування судном висвітлюються позитивні та негативні властивості при побудові адаптивних систем автоматизащії судном. Також в праці розкриваються особливістю побудови адаптації авторульових систем судна та можливості покращення якості судноводіння в складних умовах.

Пропонується розглядати судноводіння як єдиний процес керування судном з врахуванням всіх підсистем що впливають на управління в ичілому за рахунок підвищення достовірності інформащії від різних енерготехнічних систем та навігаџійних пристроїв щзо надають додаткові дані в систему керування судном.

Ключові слова: адаптивні системи, судноводіння, керування судном, автоматизована система керування

Вступ. Ефективне управління судном 3 врахуванням безпечного судноводіння забезпечується за рахунок автоматичного управління суднових вузлів, пристроїв і систем 3 можливістю вироблення керуючого впливу в реальному масштабі часу [1, 2]. Стрімкий розвиток інформаційних технологій та засобів автоматизації створили передумови i можливості не тільки щодо реалізації автоматизованих систем управління судном в складних умов, але і їх функціонування за рахунок адаптації до зовнішніх і внутрішніх дій [2]. Крім цього, аналіз інформаційно-керуючої зв'язків в архітектурі системи управління судна показав, що для забезпечення оптимального судноводіння і безпеки плавання в акваторіях потрібно систему керування судном розглядати як єдиний інтегрований комплекс, який пов'язаний з усіма технічними пристроями, засобами і вузлами на основі взаємопов'язаних спеціальних обчислювальних систем 3 наявними програмно-алгоритмічним забезпеченням 3 можливістю обробки даних i сигналів для оцінки водної обстановки i прокладки оптимального маршруту руху [3].

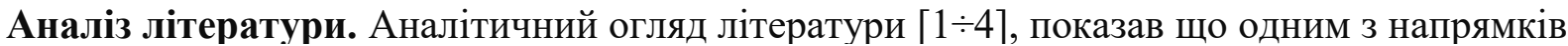
підвищення якості судноводіння і ефективності функціонування суднових технічних засобів, $\epsilon$ створення адаптивних систем управління судном, які дозволяють поліпшити процес керованості водного транспорту i забезпечують безпеку судноводіння в складних навігаційних умовах, а також помітно підвищує ефективність застосування під час їх експлуатації. Крім цього, адаптивні системи керування судном вирішують завдання не тільки судноводіння по заданому курсу щодо прямолінійної траєкторії руху, але і забезпечують оптимальне маневрування на основі надання різних даних про зовнішні умови і навігаційної обстановки [3]. Так одним з перспективних напрямів підвищення керованості судна в умовах динаміки, $є$ комплексна автоматизація з урахуванням впливу зовнішніх впливів і загальної обстановки на морі, яка здійснює автоматизацію процесів навігації та судноводіння, з одного боку, а з іншого забезпечує ефективну експлуатацію роботи енерготехнічних систем за рахунок автоматизації їх управління. При цьому розробка i впровадження нових автоматизованих систем для управління судном повинна вестися з урахуванням ергатичних особливостей для оптимального вироблення керуючого впливу [4]. Тому основний автоматизації морських суден на даному етапі $є$ розробка адаптивних систем автоматизації роботи електроенергетичних установок, палубних механізмів, вантажних пристроїв i 
приладів навігації з можливістю комплексного обліку різних динамічних впливів. Так впровадження адаптивних систем автоматизації пов'язане 3 можливістю застосування складних цифрових обчислювальних машин, з паралельною обробкою різних типів даних 3 урахуванням зовнішніх і внутрішніх впливів.

Мета статті. Тому метою даної статті є провести аналіз і представити результати досліджень щодо побудови адаптивних систем керування судном з можливістю підвищення ефективності судноводіння під час його експлуатації в складних умовах для забезпечення безпеки управління судна.

Виклад основного матеріалу. Аналіз джерел $[1,2,3]$ показав, що основними впливами на водний транспортний засіб $є$ : вплив морської поверхні і вітрового навантаження. Так на об'єкт управління (судно) вплив даних збурень призводять до зміщення заданого курсу, втрати енергії в рухових установках, а також зміна властивостей маневрування і відхилення від курсу судна.

Розглянемо особливості впливу вітрового навантаження і морської поверхні на рух судна.

Найбільший вплив на водний транспортний засіб надає вітрове навантаження, яка призводить до зміни рисканья. Так наприклад, попутний вітер призводить до збільшення нишпорення судна, а при бічному вітрі відбувається до нестаціонарним змін заданого ходу судна $з$ динамічною зміною носа і корми [3]. Також хвилювання морської поверхні сприяє до збільшення нишпорення судна, а гвинт і кермо можуть тимчасово підніматися над водною поверхнею, що також веде до зміни лінії заданого ходу і курсу з погіршенням маневреності при судноводінні [1]. В результаті вивчення літератури $[1,2]$ можна виділити наступні відхилення судна від лінії заданого курсу, викликані впливу вітрового навантаження i морського хвилювання морської поверхні на рух судна відповідно трьох типів:

зміни крену, асиметрії обводів корпусу, упору гвинтів. Спектр цих впливів низькочастотний і знаходиться в смузі пропускання системи управління судном;

зміна частотного спектра за межами смуги пропускання системи управління, викликане хвилюванням і різким поривом вітру;

зміни гідродинамічних характеристик морської поверхні, які призводять до зміни швидкості руху судна, а також до кормових навантажень і глибини під кілем (особливо це істотно на мілководді).

Для обліку впливів першого і другого типу застосовують Авторульові системи, які реагують на обурення щодо відхилення судна. При цьому, Авторульові реакція на відхилення судна від курсу, викликані збуреннями другого типу, що знаходяться поза смуги пропускання системи управління, призводить до форсованого впливу на рульовий привід, що не сприяє стабілізації судна на курсі і є одним з недоліків таких систем $[1,2]$. Зазначений недолік усувають, введенням запізнювання в контур управління або застосуванням фільтра низьких частот на вході авторульового [4].

Третій тип збурень призводять до відхилення від курсу. В даному випадку, при постійному контролі й компенсації в системі автоматичного регулювання не можливо усунути вплив за допомогою зворотного зв'язку [4]. Дослідження збурень третього типу показав, що для оптимального управління судном необхідно виробляти перенастроювання параметрів регулятора, тобто змінювати закону регулювання, що призводить до зміни схеми управління судном $[1,2,4]$. В даному випадку зміни не враховуються в перенастроюванні регулятора, що призводить до втрат корисної потужності енергетичної установки, за рахунок $[3,4]$ :

збільшення шляху через відхилення від заданого курсу на частоту власних коливань судна;

додатковому опору води при русі корпусу і керма внаслідок появи кута дрейфу судна;

гальмування судна під впливом кутової швидкості нишпорення і лінійної швидкості бокового зміщення судна, а також при одночасному дрейфі і нишпоренні.

Чи не врахування зовнішніх факторів призводить до додаткової витрати палива при управлінні судном. 
Таким чином, в ході проведених досліджень структурного побудова системи управління морського транспортного засобу можна виділити ряд вимог, які суттєво впливають на побудову адаптивних систем управління судном для здійснення оптимального судноводіння, такі як:

1. Визначення, оцінка та облік зовнішніх впливів впливають на технічні засоби управління судном під час експлуатації, в тому числі метеорологічних умов $[1,3,5]$.

2. Забезпечення достовірності, своєчасності та надійності циркулюючої інформації в системі управління судном. При цьому автоматизована система управління судном повинна відповідати наступним принципам [3, 5]:

- функціональна автономія технічних засобів, в тому числі прийому і обробки первинної інформації (сигналів);

- модульний принцип побудови системи управління технічними засобами, а також функціональна незалежність обладнання друг від друга;

- функціональна надлишковість циркулюючої інформації 3 можливістю дублювання деяких видів завдань функціонування судна;

- можливість проведення оцінки та обчислення похибок в аналого-цифровому тракті для передачі інформації в систему обробки;

- можливість здійснення постійного систем контролю первинної інформації (сигналів), в тому числі стану ланцюгів передачі (вузлів і контурів) в автоматизованій системі управління судном;

- абезпечення надійної і безвідмовної роботи технічних засобів, вузлів і контурів.

3. Реалізація цифрової обробки інформації в системі управління судном з можливістю проміжного контролю і відображення даних [5].

4. Можливість в реальному масштабі часу передачі інформації (сигналів) в інформаційно-керуючої системи судна, зі збереженням своїх характеристик, в тому числі і в несприятливих умовах навколишнього середовища $[3,5]$.

3 огляду на вищевикладене та аналізуючи літературу [4 7], можна прийти до висновку про необхідність своєчасного реагування на зміни в системі управління судном. Таким чином, система управління повинна мати властивість перенастроювання параметрів $\mathrm{i}$ здійснювати «пристосування» до зміни внутрішніх і зовнішніх умов роботи. На сучасному етапі побудови суднових адаптивних систем поширені адаптивні Авторульові, в яких проводиться автоматична перебудова параметрів регулятора відповідно до заданого критерію оптимальності [3, 4]:

стабілізація судна за курсом за рахунок збільшення швидкості ходу і витрачається потужності;

максимальна точність стабілізації за курсом відповідно навігаційної безпеки 3 мінімальною втратою палива;

маневр відповідно заданими характеристиками по швидкості повороту з заданим радіусом кривизни.

В даному випадку адаптивні Авторульові виконують функцію оптимальної перенастроювання параметрів системи управління судном при зміні його стану в умовах зовнішніх впливу. При цьому їх можна розділити на дві основні групи [4]:

1. Група: в адаптаційної схемою в системі управління судном використовується еталонна математична модель судна (див. Рис.1 а) - автономні системи управління.

2. Група: в адаптаційної схемою в системі управління судном використовуються інформація про зовнішні дії (див. Рис.1 б) - неавтономні системи управління.

Відмінність даних груп полягає в способі формування керуючих сигналів, які впливають на систему управління судном.

Так в першій групі при автономному Авторульові сигнал формується на основі аналізу можливості управління судна за курсом і текучим вимірам, а також з модельований вихідних параметрів судна всієї системи управління. В даному випадку, такими параметрами є кут відхилення від курсу і швидкості зміни. При цьому, особливістю автономних адаптивних Авторульові $\epsilon$ наявність еталонної математичної моделі, заснованої на диференціальних рівняннях руху судна з бажаними гідродинамічними характеристиками [3]. 
Процес адаптації здійснюється наступним чином. На вхід еталонної моделі надходить таке ж керуючий вплив, як на реальний об'єкт (рис. 1a). 3 виходу моделі знімається сигнал кутової швидкості повороту, який відповідає бажаної реакції судна. Обчислюється зміна різниці і відбувається порівняння кутової швидкості повороту 3 фактичної кутовий швидкістю водного транспорту. При цьому, різниця показує вимір коригуючого сигналу. В даному випадку адаптація відбувається щодо зміни і здійснюється автоматична настройка параметрів управління на основі коригуючого сигналу.

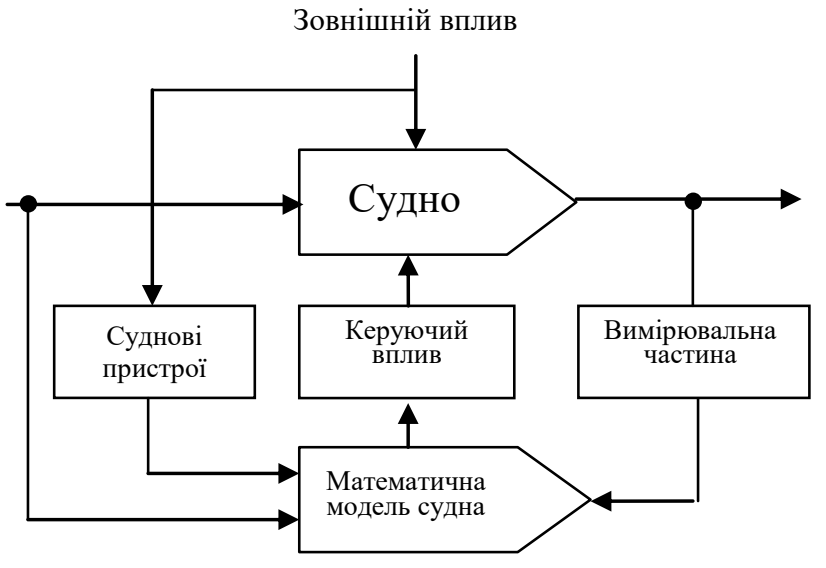

a)

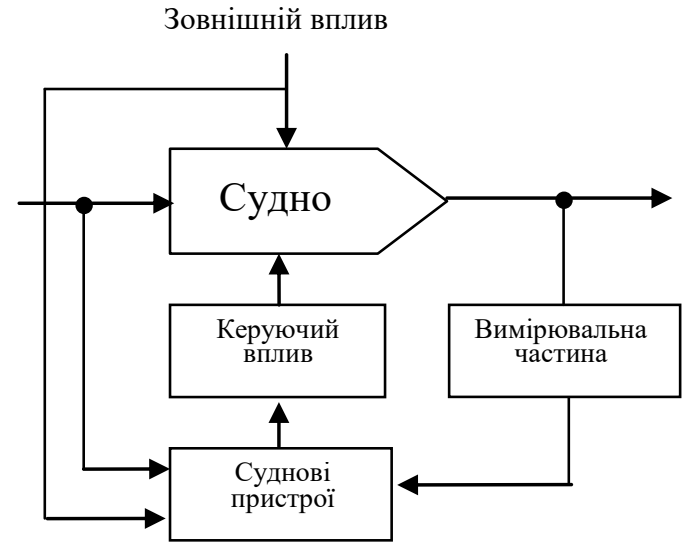

б)

Рисунок 1 - Загальні схеми:

а) адаптована система управління судном з використанням математичної моделі;

б) адаптована система управління судном з використанням суднових пристроїв.

У другій групі адаптація авторульового здійснюється на основі заздалегідь встановленої залежності змін управління судном від зовнішніх умов: глибини під кілем, швидкості, завантаження судна, хвилювання моря і т.д. [1, 3]. Зміна зовнішніх умов оцінюється за допомогою відповідних датчиків, таких як: ехолот, лаг, вимірювача качки i інші. При цьому, обурення, що діють на систему управління судном, призводять до відхилення його від заданого курсу і до зміни параметрів руху як об'єкта управління. Такі системи відносяться до автономних пошуковим системам. При цьому, особливістю неавтономних систем адаптивного управління Авторульові $є$ використання додаткового контуру самонастроювання, який забезпечує виконання наступних функцій $[1,3,4]$ :

додаткова інформація про зовнішні дії, а також про властивості основного контуру в динамічному режимі системи управління в процесі експлуатації;

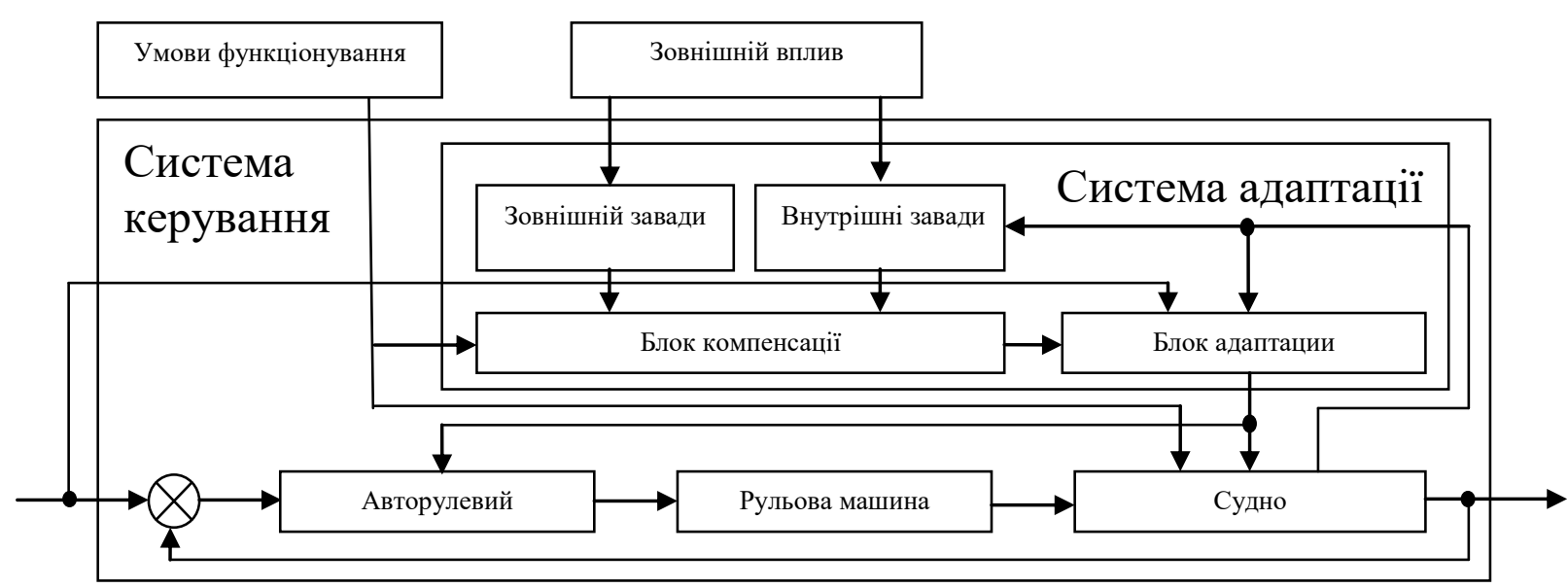

Рисунок 2 - Схема неавтономної адаптивної системи керування судном 
обчислення ефективності по заданому критерію якості на основі інформації, що використовується;

забезпечення оптимального режиму роботи системи управління судна на основі вироблення керуючого сигналу для мінімізації за обраним критерієм якості.

Відповідно вищевикладеного неавтономні адаптивні системи управління судном (рис.

2) можна поділити на дві групи $[5,6]$ :

настройка системи управління по оптимальних значень параметрів;

аналіз статистичних даних в процесі управління 3 можливістю адаптації системи управління.

В даному випадку настройка системи управління по оптимальних значень параметрів залежить від перенастроювання Авторульові з адаптацією, яка здійснюється за обраним критерієм якості. Так у схемі авторулёвого використовується спеціалізований обчислювальний комплекс з набором програм і в разі надходження інформація від суднових датчиків (гірокомпас, лаг, маятникового кренометр і інші) виробляється перенастроювання енерготехнічна системи судна за обраним критерієм. На сьогоднішній день вимірювальна інформація, яка надходитиме від датчиків (первинна інформація) енергетичних установок обробляється за допомогою алгоритму Калмана, який служить для виділення корисного сигналу управління на тлі перешкод, викликаних відхиленням судна від курсу при хвилюванні [6 7]. Алгоритм Калмана досить вивчений і дозволяє забезпечувати вироблення оцінок параметрів руху судна, необхідних для оптимізації налаштування авторульового i прогнозування бажаної реакції судна на дії. Крім цього, даний алгоритм визначає оптимальні значення параметрів настройки авторульового. Про даному алгоритмі написано багато літератури, в якій по кроків розписані дії про його виконанні.

Також на сучасному етапі розвитку систем управління судном в деяких типах Авторульові використовуються дані отримані від системи автоматичного регулювання рухом судна відповідно динаміки роботи по курсу в різних умовах функціонування [6, 7]. Це здійснюється за допомогою бортових обчислювальних комплексів за спеціальними програмами. Застосування даних програм здійснюється в залежності від набору текучих параметрів швидкості судна, смуги пропускання частот системи, а також вибору критерію якості.

У другій групі: використання Авторульові 3 адаптацією, заснованої на аналізі статистичних даних в процесі управління, необхідно розглядати поведінку судна як стаціонарний випадковий процес. В даному випадку поведінка руху судна можна описати за допомогою багатовимірної моделі, яка визначається процедурою пошуку мінімуму інформаційного критерію [7]. При цьому математична модель ненадійна. Це пов'язано з тим що виникає необхідність забезпечувати високу точність апріорної інформації від зовнішніх впливів. В даному випадку апроксимація процесу чутлива до статистичного шуму $\mathrm{i}$ призводить до огрубіння отриманих первинних результатів. Застосовуючи цю модель, необхідно проводити аналіз спектра змінних стану судна і обчислювати оптимальні значення параметрів настройки системи. Обробка поточних параметрів моделі здійснюється за допомогою методу максимальної правдоподібності. Тому в адаптивних Авторульові найбільшого поширення набули економічні критерії якості управління $[6,7]$. Це пов'язано 3 простотою оцінки ефективності різних економічних критеріїв, які залежать від погодних умов.

На сучасному розвитку обчислювальної техніки пропонується створення об'єднаного комплексу управління судном в якому процес керування судном буде розглядати як єдиний під час судноводіння з врахуванням всіх підсистем що впливають на управління в цілому. Одним із перспективних напрямків $є$ необхідність більшої інтеграції систем управління судном в умовах забезпечення встановлених вимог судноводіння на основі інтеграції системи керування та енергетичних підсистем судна. Це дає можливість не тільки полегшити процес адаптації систем керування судном, але і підвищити достовірність прийняття рішення під час управління судном в складних умовах та отримання своєчасної інформації від різних енерготехнічних систем та навігаційних пристроїв що надають додаткові дані в систему керування судном. 
Висновки. Аналізуючи літературу та досвід експлуатаційної роботи, можна зробити висновок, що створення і впровадження в практику адаптивних систем керування судном $\epsilon$ перспективним. Це пов'язано з тим, що виникає необхідність здійснювати судноводіння в складних умовах, а також розвитком нових шляхів реалізації Е-навігації.

\section{ЛІТЕРАТУРА}

1. Вагущенко Л.Л. Системы автоматического управления движением судна // Л.Л. Вагущенко, Н.Н. Цымбал. - Одесса: Фенікс, 2007. - 328 с.

2. Карасев В.В. Современная система автоматизация судовождения / В.В. Карасев, Н.В. Вовченко. - Владивосток: Дальрыбвтуз, 2005. - 108 с.

3. Баранов Г.Л. Функціональна стійкість навігаційного обслуговування безпеки судноплавства на внутрішніх водних шляхах / Г.Л. Баранов, А.М. Носовський, I.В. Тихонов // Монографія - Київ: КДАВТ, 2012. - 149 с.

4. Власов К.П. Теория автоматического управления / К.П. Власов. - Харьков: Изд-во Гуманитарный центр, 2007. - 526 с.

5. Вагущенко Л.Л. Современные информационные технологии в судовождении / Л.Л. Вагущенко - Одесса: ОНМА, 2013. - 135 с.

6. Артемов Г.А. Суднові енергетичні установки / Г.А. Артемов, В.М. Горбов. - Миколаїв: УДМТУ, 2002. - $356 \mathrm{c.}$

7. Носенко В.М. Судовые энергетические установки / В.М. Носенко. - Николаев: ФЛН Швед В.Д., 2013. - 443 с.

Тимощук О.М., Дакі О.А., Бойко О.А., Карадобрій Т. А. ANALYTICAL INSPECTION OF ADAPTIVE VESSEL CONTROL SYSTEMS AND WAYS OF THEIR CONSTRUCTION

The article presents the main results of the analysis of information sources related to the construction of adaptive systems for ship control.

Along with the analytical review of technical solutions of ship control systems, the positive and negative properties in the construction of adaptive ship automation systems are highlighted. The paper also reveals the peculiarity of the construction of the adaptation of the rudder systems of the ship and the possibility of improving the quality of navigation in difficult conditions. It is proposed to consider navigation as a single process of ship control, taking into account all subsystems that affect control in general by increasing the reliability of information from various energy systems and navigation devices that provide additional data to the ship control system.

Key words: adaptive systems, navigation, ship control, automated control systems

\section{Tymoshchuk O.M., Daki O.A., Boyko O.A., Karadobriy T.A. АНАЛИТИЧЕСКИЙ ОБЗОР АДАПТИВНЫХ СИСТЕМ УПРАВЛЕНИЯ СУДНОМ И ПУТИ ИХ ПОСТРОЕНИЯ}

В статье отображаются основные результаты анализа источников информации связанные с построения адаптивных систем управления судном. На ряду с аналитическим обзором технических решений систем управления судном освещаются положительные $и$ отрицательные свойства при построении адаптивных систем автоматизации судном. Также в работе раскрываются особенностью построения адаптации авторулевого систем судна и возможности улучшения качества судовождения в сложных условиях. Предлагается рассматривать судовождения как единый процесс управления судном с учетом всех подсистем влияющие на управление в цеелом за счет повышения достоверности информации от различных энерготехнических систем и навигачионных устройств, предоставляющих дополнительные даннье в систему управления судном.

Ключевые слова: адаптивные системь, судовождение, управление судном, автоматизированная система управления 